\title{
Pharmacokinetics and Pharmacodynamics of the Proton Pump Inhibitors
}

\author{
Jai Moo Shin ${ }^{1 *}$ and Nayoung Kim $^{2}$ \\ ${ }^{1}$ Jai Scientific, Los Angeles, California, USA; and ${ }^{2}$ Division of Gastroenterology, Seoul National University Bundang Hospital, and Department \\ of Internal Medicine, Seoul National University College of Medicine, Seoul, Korea
}

Proton pump inhibitor (PPI) is a prodrug which is activated by acid. Activated PPI binds covalently to the gastric $\mathrm{H}^{+}, \mathrm{K}^{+}$ -ATPase via disulfide bond. Cys813 is the primary site responsible for the inhibition of acid pump enzyme, where PPIs bind. Omeprazole was the first PPI introduced in market, followed by pantoprazole, lansoprazole and rabeprazole. Though these PPIs share the core structures benzimidazole and pyridine, their pharmacokinetics and pharmacodynamics are a little different. Several factors must be considered in understanding the pharmacodynamics of PPIs, including: accumulation of PPI in the parietal cell, the proportion of the pump enzyme located at the canaliculus, de novo synthesis of new pump enzyme, metabolism of PPI, amounts of covalent binding of PPI in the parietal cell, and the stability of PPI binding. PPIs have about 1 hour of elimination half-life. Area under the plasmic concentration curve and the intragastric $\mathrm{pH}$ profile are very good indicators for evaluating PPI efficacy. Though CYP2C19 and CYP3A4 polymorphism are major components of PPI metabolism, the pharmacokinetics and pharmacodynamics of racemic mixture of PPIs depend on the CYP2C19 genotype status. S-omeprazole is relatively insensitive to CYP2C19, so better control of the intragastric pH is achieved. Similarly, R-lansoprazole was developed in order to increase the drug activity. Delayed-release formulation resulted in a longer duration of effective concentration of R-lansoprazole in blood, in addition to metabolic advantage. Thus, dexlansoprazole showed best control of the intragastric pH among the present PPIs. Overall, PPIs made significant progress in the management of acid-related diseases and improved health-related quality of life.

(J Neurogastroenterol Motil 2013;19:25-35)

Key Words

Area under the plasmic concentration curve; Hydrogen potassium ATPase; Gastric acid; Gastric endogenous activator protein, mammal; Pharmacokinetics; Pharmacology; Proton pump inhibitors

\section{Introduction}

Since the parietal cell was known to secrete gastric acid, many drugs were developed to target the parietal cell in order to inhibit the acid secretion. The major functional targets in the parietal cell were the histamine type $2(\mathrm{H} 2)$ receptor and the gastric $\mathrm{H}^{+}, \mathrm{K}^{+}$ -ATPase. ${ }^{1,2}$ Histamine binds to the $\mathrm{H} 2$ receptor, leading to elevation of intracellular cyclic AMP concentrations and activation of protein kinase A (PKA). One effect of PKA activation is the

Received: December 11, 2012 Revised: December 20, 2012 Accepted: December 21, 2012

(c) This is an Open Access article distributed under the terms of the Creative Commons Attribution Non-Commercial License (http://creativecommons. org/licenses/by-nc/3.0) which permits unrestricted non-commercial use, distribution, and reproduction in any medium, provided the original work is properly cited.

*Correspondence: Jai Moo Shin, PhD

20000 Tuba Street, Chatsworth, CA 91311, USA

Financial support: None. Tel: +1-818-523-6913, E-mail: jaimooshin@gmail.com

Conflicts of interest: None.

Author contributions: Jai Moo Shin and Nayoung Kim equally contributed in planning the manuscript, collecting the data and writing the manuscript. 
phosphorylation of cytoskeletal proteins involved in the transport of the gastric $\mathrm{H}^{+}, \mathrm{K}^{+}$-ATPase from cytoplasm to the plasma membrane, i.e., from the vesicular and/or tubular vesicular membrane to the canaliculus. In the canaliculus, the gastric $\mathrm{H}^{+}, \mathrm{K}^{+}$ -ATPase can access $\mathrm{KCl}$ of the extracellular region and exchange the intracellular proton with the extracellular $\mathrm{K}$ ion, which represents the gastric acid secretion. The $\mathrm{H} 2$ receptor is crucial in making the acid secreting morphology of the parietal cell, while the gastric $\mathrm{H}^{+}, \mathrm{K}^{+}$-ATPase is the final functional work on the acid secretion.

The H2 receptor antagonist was first introduced in $1977^{1,3}$ and dramatically increased the healing rates of peptic ulcer disease. The receptor antagonist, however, showed limited healing effects on the gastroesophageal reflux disease (GERD) since the antagonist provided limited $\mathrm{pH}$ control in the stomach. In order to get better $\mathrm{pH}$ control in the stomach, the acid secreting enzyme was considered as a drug target. The proton pump inhibitor (PPI), introduced in 1989, targeted the gastric $\mathrm{H}^{+}, \mathrm{K}^{+}$-ATPase and reflected a major medical therapeutic breakthrough in the treatment of peptic ulcers and GERD, resulting in more rapid healing of the lesions and symptom relief.

PPI is a prodrug which is activated by acid. PPI inhibits the gastric $\mathrm{H}^{+}, \mathrm{K}^{+}$-ATPase by covalent bonding at cysteines near the ion pathway. Due to the property of covalent bonds, the inhibitory activity lasts longer.

\section{Structure of the Gastric $\mathrm{H}^{+}, \mathrm{K}^{+}$-ATPase}

The gastric $\mathrm{H}^{+}, \mathrm{K}^{+}$-ATPase is an $\alpha, \beta$-heterodimeric enzyme. The $\alpha$ subunit, with molecular mass of about $100 \mathrm{kDa}$, has the catalytic site and the $\beta$ subunit, with peptide mass of 35 $\mathrm{kDa}$, is strongly but non-covalently associated with the $\alpha$ subunit.

The gastric $\alpha$ subunit has conserved sequences along with the other $\mathrm{P}_{2}$ type ATPases, the sarcoplasmic reticulum $\mathrm{Ca}^{2+}$-ATPase and the $\mathrm{Na}^{+}, \mathrm{K}^{+}$-ATPase, for the ATP binding site and the phosphorylation site. The phosphorylation site was observed to be at Asp386, ${ }^{4}$ which is well conserved in other P-type ATPases. The membrane topology of the $\alpha$ subunit has been shown to contain 10 membrane spanning segments. ${ }^{5-7}$ The $\beta$ subunit consists of about 290 amino acids with a single transmembrane segment, which is located at the region near the $\mathrm{N}$-terminus. There are 3 disulfide bridges in the luminal region of the $\beta$ subunit. ${ }^{8,9}$ Six and seven putative N-glycosylated sites (AsnXaaSer and AsnXaaThr) are found in pig and rabbit, respectively. ${ }^{10-12}$ Seven N-glycosylated sites of the gastric $\mathrm{H}^{+}, \mathrm{K}^{+}$-ATPase $\beta$ subunit are conserved in rat and human.
The $\alpha$ subunit of the $\mathrm{H}^{+}, \mathrm{K}^{+}$-ATPase is strongly associated with the $\beta$ subunit. ${ }^{13}$ The region of the sequence Arg898 to Arg922 in the $\alpha$ subunit was known to have strong interactions with the extracytoplasmic domain of the $\beta$ subunit. In the plasma membrane, the gastric $\mathrm{H}^{+}, \mathrm{K}^{+}$-ATPase may function as an $(\alpha-\beta)_{2}$ dimeric heterodimer. ${ }^{14}$ The important observation was that the membrane preparation showed full stoichiometry with respect to ATP binding ( $1 \mathrm{~mol} / \mathrm{mol}$ of $\alpha-\beta)$ and half stoichiometry with respect to inhibitor binding and phosphorylation, suggesting an $(\alpha-\beta)_{2}$ oligomer.

The $\mathrm{H}^{+}, \mathrm{K}^{+}$-ATPase $\alpha$-subunit is composed of 10 transmembrane helices (TM1 through TM10) and 3 cytosolic domains: N (nucleotide binding), $\mathrm{P}$ (phosphorylation) and A (activation) (Fig. 1). Recently, 2 dimensional crystals of the $\mathrm{H}^{+}, \mathrm{K}^{+}$-ATPase were analyzed in the presence of the phosphate analog $\mathrm{BeF}$ and an inhibitor $\mathrm{SCH} 28080 .^{15,16}$ This structure of the $\mathrm{E}_{2} \mathrm{P}$ conformation was similar to that of $\mathrm{Ca}^{2+}$-ATPase. The overall structure shows characteristic features of the $\mathrm{ADP}$-insensitive $\mathrm{E}_{2} \mathrm{P}$ conformation, to which SCH28080 is preferentially bound. The BeF-bound phosphorylation site (Asp386) at the $\mathrm{P}$ domain is covered by the A domain, and the ADP-bound $\mathrm{N}$ domain is separated from the $\mathrm{P}$ domain, thus the bound phosphate analog seems to be isolated from both ADP and the bulk solution.

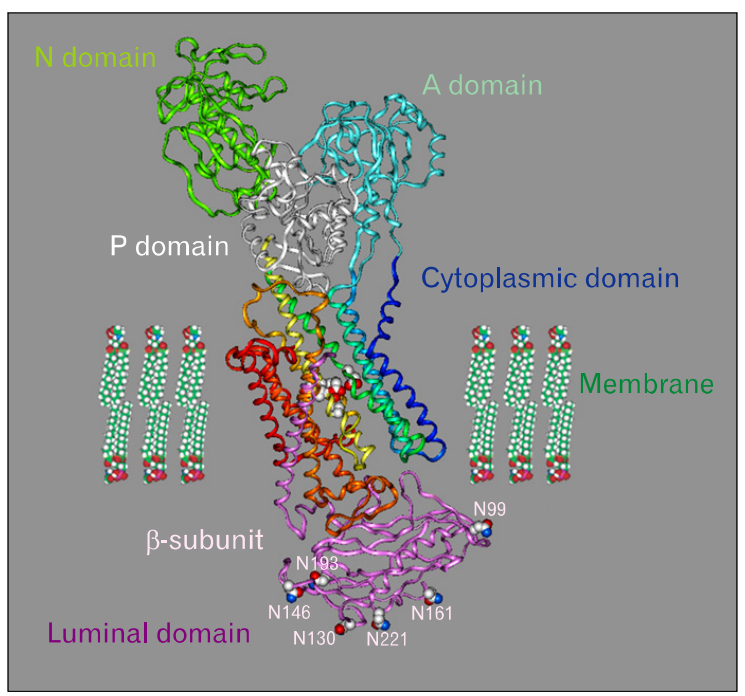

Figure 1. A model structure of the gastric $\mathrm{H}^{+}, \mathrm{K}^{+}$-ATPase. The gastric $\mathrm{H}^{+}, \mathrm{K}^{+}$-ATPase $\alpha$ subunit has 3 lobes, $\mathrm{N}$ (ATP binding), $\mathrm{P}$ (phosphorylation) and A (activation) domains in the cytoplasmic domain, and 3 transmembrane segments in the membrane domain. The gastric $\beta$ subunit has short cytoplasmic region, 1 transmembrane segment, and a heavily glycosylated extracellular region. The number of Asn sites having carbohydrates is based on pig $\mathrm{H}^{+}, \mathrm{K}^{+}$-ATPase. 


\section{Proton Pumping Mechanism of the Gastric $\mathrm{H}^{+}, \mathrm{K}^{+}$-ATPase}

The $\mathrm{H}^{+}, \mathrm{K}^{+}$-ATPase exchanges intracellular hydrogen ions for extracellular potassium ions by consuming ATP. The $\mathrm{H}^{+} / \mathrm{ATP}$ ratio was independent of external $\mathrm{KCl}$ and ATP concentration. However, the stoichiometry of $\mathrm{H}^{+}$per ATP was different depending on the luminal $\mathrm{pH}$. The $\mathrm{H}^{+}$for $\mathrm{K}^{+}$stoichiometry of the $\mathrm{H}^{+}, \mathrm{K}^{+}$-ATPase per ATP hydrolyzed was 1 at low $\mathrm{pH}$, and 2 at neutral $\mathrm{pH}$ or near neutral $\mathrm{pH}$.

The $\mathrm{H}^{+}, \mathrm{K}^{+}$-ATPase has many reaction steps for pumping the proton (Fig. 2). The $\mathrm{H}^{+}, \mathrm{K}^{+}$-ATPase binds the hydronium ion on the cytoplasmic side at high affinity, which is called $\mathrm{E}_{1}$ conformation. The initial step is the reversible binding of ATP to the enzyme in the absence of added $\mathrm{K}^{+}$ion, followed by a $\mathrm{Mg}^{2+}$ (and hydronium) dependent transfer of $\gamma$-phosphate of ATP to Asp386 of the catalytic subunit $\left(\mathrm{E}_{1}-\mathrm{P} \cdot \mathrm{H}^{+}\right)$. Following phosphorylation, the conformation changes from $\mathrm{E}_{1} \mathrm{P} \cdot \mathrm{H}_{3} \mathrm{O}^{+}$to the $\mathrm{E}_{2} \mathrm{P} \cdot \mathrm{H}_{3} \mathrm{O}^{+}$form, which has high affinity for $\mathrm{K}^{+}$and low affinity for $\mathrm{H}_{3} \mathrm{O}^{+}$, allowing release of $\mathrm{H}_{3} \mathrm{O}^{+}$and binding of $\mathrm{K}^{+}$from the extra-cytoplasmic surface of the enzyme. Breakdown of the $\mathrm{E}_{2} \mathrm{P}$ form requires $\mathrm{K}^{+}$or its congeners on the outside face of the enzyme. With dephosphorylation, the $\mathrm{E}_{1} \mathrm{~K}^{+}$conformation is produced with a low affinity for $\mathrm{K}^{+}$, releasing $\mathrm{K}^{+}$to the cytoplasmic side and allowing rebinding of $\mathrm{H}_{3} \mathrm{O}^{+}$.

The addition of $\mathrm{K}^{+}$to the enzyme-bound acyl phosphate re-

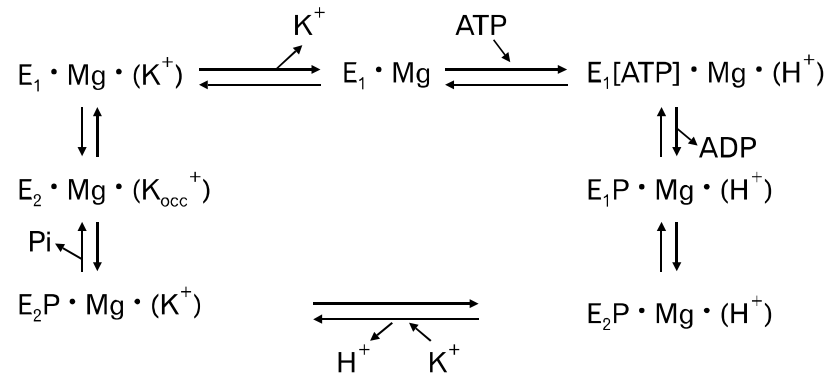

Figure 2. The catalytic cycle of the gastric $\mathrm{H}^{+}, \mathrm{K}^{+}$-ATPase. A hydronium ion binds to the cytoplasmic surface of the gastric $\mathrm{H}^{+}, \mathrm{K}^{+}$ -ATPase ( $\mathrm{E}_{1}$ form $)$ and ATP phosphorylates the protein at Asp386 to form the first ion transport intermediate in the $\mathrm{E}_{1} \mathrm{P}$ form. The $\mathrm{E}_{1} \mathrm{P}$ form then converts by a conformational change to the second ion transport form, $\mathrm{E}_{2} \mathrm{P}$, with the ion site now exposed to the exterior and hydronium is released. To this form, $\mathrm{K}^{+}$binds from the outside surface to the same region from which the hydronium was released, and the enzyme dephosphorylates, and then $\mathrm{K}^{+}$is trapped within the membrane domain in the occluded form. The $\mathrm{K}^{+}$is then de-occluded allowing reformation of the $E_{1}$ form of the enzyme with the ion site now again facing the cytoplasm and $\mathrm{K}^{+}$is displaced when ATP is bound. sults in a biphasic dephosphorylation. The faster initial step is dependent on the concentration of $\mathrm{K}^{+}$, whereas the slower step is not affected by $\mathrm{K}^{+}$concentration. The second phase of phosphoenzyme breakdown is accelerated in the presence of $\mathrm{K}^{+}$but, at $\mathrm{K}^{+}$ concentrations exceeding $500 \mu \mathrm{M}$, the rate becomes independent of $\mathrm{K}^{+}$concentration. This shows that 2 forms of phosphoenzyme exist. The first form, presumably $\mathrm{E}_{1} \mathrm{P}$ is $\mathrm{K}^{+}$insensitive and converts spontaneously in the rate-limiting step to $\mathrm{E}_{2} \mathrm{P}$, the $\mathrm{K}^{+}$sensitive form. ATP binding to the $\mathrm{H}^{+}, \mathrm{K}^{+}$-ATPase occurs in both the $\mathrm{E}_{1}$ and the $\mathrm{E}_{2}$ state, but with a lower affinity in $\mathrm{E}_{2}$ state. ${ }^{17}$ The $\mathrm{Mg}^{2+}$ remains occluded in the $\mathrm{P}$ domain near Asp730 ${ }^{18}$ until dephosphorylation in contrast to the $\mathrm{Na}^{+}, \mathrm{K}^{+}$-ATPase where the $\mathrm{Mg}$ ion is released from $\mathrm{E}_{2} \mathrm{P} .{ }^{19}$

\section{Proton and Potassium Ion Pathway}

A model of $\mathrm{H}^{+}$and $\mathrm{K}^{+}$transport was proposed as follows. ${ }^{20}$ There is a ion channel gate at the middle of the membrane where transmembrane segments TM5, TM6 and TM3, and 3 hydronium ion binding sites ( $\mathrm{H} 1, \mathrm{H} 2$ and $\mathrm{H} 3)$ exist. The $\mathrm{H} 1$ hydronium ion binding site consists of E795, E936 and D824. The hydronium site $\mathrm{H} 2$ consists of E795, E820 and D824. $\mathrm{Lys}^{-\mathrm{NH}_{3}}{ }^{+}$ -791 is above the hydronium site $\mathrm{H} 2$. With phosphorylation and formation of $\mathrm{E}_{1} \mathrm{P}, \mathrm{K} 791$ moves into the second hydronium site containing E795, E820 and D824 forming $\mathrm{E}_{2} \mathrm{P}$ and the lys- $\mathrm{NH}_{3}{ }^{+}$ displaces the $\mathrm{H}_{3} \mathrm{O}^{+}$outward. At $\mathrm{pH}<3.0$, the hydronium at $\mathrm{H} 1$ remains bound due to the higher $\mathrm{pK}_{\mathrm{a}}$ of this site so the $\mathrm{K}^{+}$ binds only at H2, displacing K791 upward. With dephosphorylation, $\mathrm{K}^{+}$moves into $\mathrm{H} 3$, where E820, E343 and the carbonyls of V337 and V341 are reoriented to allow the exiting of $\mathrm{K}^{+}$along TM3. Critical to the coupling of ATP binding and subsequent phosphorylation is the conformational change where the A domain rotates clockwise to bring the $\mathrm{N}$ and $\mathrm{P}$ domain into apposition, with the bound ATP acting like a hook to retain this conformation until dephosphorylation.

The model generated for the $\mathrm{E}_{2} \mathrm{P}$ conformation showed a channel for the passage of $\mathrm{K}^{+}$from the luminal vestibule to the ion occlusion site near the middle of the membrane. The M5/M6 loop presents the first protein segment encountered for passage of the ion into the channel. The only pathway to the site accessed by the ion is between the carbonyl oxygens of L811 and G812 and the thiol of $\mathrm{C} 813$. This leads to apparent binding to these 2 carbonyls and 2 molecules of water. This appears from the model to be the initial entry site into the channel. A notable feature of the luminal face of the enzyme modeled in the $\mathrm{E}_{2}$ form is the presence of a luminal vestibule bounded by TM4, TM5 and TM6 


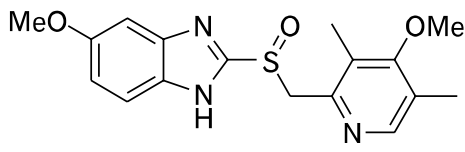

Omeprazole

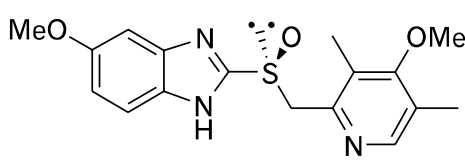

Esomeprazole

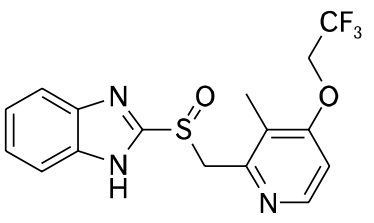

Lansoprazole

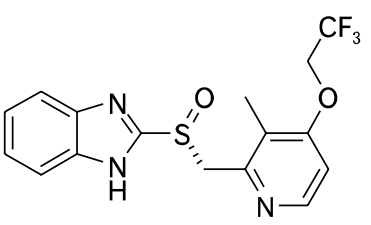

Dexlansoprazole<smiles>COc1ccnc(CS(=O)c2nc3cc(OC(F)F)ccc3[nH]2)c1OC</smiles>

Pantoprazole

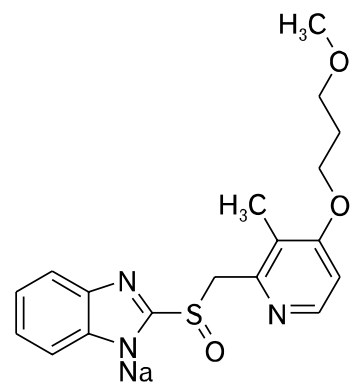

Rabeprazole

Figure 3. Structures of proton pump inhibitors.

and the connecting exoplasmic loops between TM3-TM4 and TM5-TM6 containing Cys813 as part of the loop between TM5 and TM6. This vestibule is a natural exit and entry point for transported cations, and also provides access to the different classes of inhibitors of the gastric $\mathrm{H}^{+}, \mathrm{K}^{+}$-ATPase such as the PPIs and the acid pump antagonists. Proton pump inhibits the pump enzyme by covalently binding to the thiol of Cys813. Depending on the structure of the PPI, additional binding sites at different site were observed.

\section{Proton Pump Inhibitors}

Since a substituted benzimidazole was first reported to inhibit the $\mathrm{H}^{+}, \mathrm{K}^{+}$-ATPase, ${ }^{2}$ many inhibitors of the $\mathrm{H}^{+}, \mathrm{K}^{+}$-ATPase have been synthesized (Fig. 3). The first pump inhibitor used clinically was 2-[(3, 5-dimethyl-4-methoxypyridin-2-yl) methylsulfinyl]-5-methoxy-1H-benzimidazole, omeprazole. ${ }^{21}$ This compound is a weak base $\sim \mathrm{pK}_{\mathrm{a}} 4$. The $\mathrm{H}^{+}, \mathrm{K}^{+}$-ATPase in the parietal cell secretes acid into the secretory canaliculus generating a $\mathrm{pH}$ of $<1.0$ in the lumen of this structure. The acidity of this space allows accumulation of weak bases of this $\mathrm{pK}_{\mathrm{a}}$. Weak bases of a $\mathrm{pK}_{\mathrm{a}}$ less than 4.0 can be accumulated only in this acidic space and no other acidic space in the body. Then, this compound is rapidly activated by the high acidity and inhibits acid secretion by binding to the cysteines accessible to the activated form. Other covalent binding inhibitors belonging to the substituted benzimidazole family were followed. ${ }^{22-24}$ These reagents are weak base, acid activated compounds, which form cationic sulfenamides or sulfenic acids in highly acidic environments. The thiophilic compounds formed react with the $\mathrm{SH}$ group of cysteines in the ATPase to form relatively stable disulfides (Fig. 4). ${ }^{6,7,25-27}$ Since the pump generates acid on its extra-cytoplasmic surface, only those cysteines available from that surface are accessible to these reagents if labeling is carried out under acid transporting conditions.

Omeprazole has a stoichiometry of 2 moles inhibitor bound per mole phosphoenzyme under acid transporting conditions and is bound only to the $\alpha$ subunit even in vivo. ${ }^{28-30}$ The binding sites of omeprazole are Cys813 and Cys892. The sites of reaction of the different PPIs on the enzyme differ according to the particular PPI. However, all PPIs react with Cys813 in the loop between TM5 and TM6 that fixes the enzyme in the $\mathrm{E}_{2}$ configuration. Lansoprazole reacts with Cys813 and Cys321, these being in the luminal vestibule, ${ }^{6}$ whereas pantoprazole reacts with Cys813 and Cys822., ${ }^{7,27,31}$ The reaction with Cys822 confers a rather special property to the covalently inhibited enzyme, namely irreversibility to reducing agents in vitro and in vivo due to the lack of accessibility of Cys822. An innovation was introduced by specific enantiomer (e.g., the S-enantiomer of omeprazole, esomeprazole, and the R-enantiomer of lansoprazole, dexlansoprazole). This specific enantiomer has an advantage over metabolism.

\section{Cellular Mechanism of Proton Pump Inhibitors in the Stomach}

In the human body, the only acidic space below $\mathrm{pH} 4$ is the 
stomach. With the realization that these PPIs are weak bases with a $\mathrm{pK}_{\mathrm{a}}$ between $\sim 4.0$ (omeprazole, lansoprazole and pantoprazole) and 5.0 (rabeprazole), it was clear that they would accumulate in the acidic space of the secretory canaliculus of the stimulated parietal cell. ${ }^{27}$ This acid space dependent concentration of the PPIs is their first important property that determines their therapeutic index, giving a concentration at the luminal surface of the pump that is about 1000-fold of that in the blood. The second vital step is the low $\mathrm{pH}$ dependent conversion from the accumulated prodrug to the activated species that is a highly reactive cationic thiophilic reagent. This means that protonation of these compounds is required for their activation to form disulfides with cysteines of the $\mathrm{H}^{+}, \mathrm{K}^{+}$-ATPase. The order of acid stability is pantoprazole $>$ omeprazole $>$ lansoprazole $>$ rabeprazole. When the rate of conversion of different compounds was measured as a function of $\mathrm{pH}$, it was found that the $\mathrm{pH}$ dependence of activation reflected protonation of the benzimidazole moiety. ${ }^{27}$ This explained the different activation rates among the PPIs. The chemical reaction pathway for acid activation of the PPIs is shown in Figure 4.

PPIs are prodrugs, effective only after protonation as discussed above. After accumulation in the stimulated secretory canaliculus of the parietal cell and binding to the gastric $\mathrm{H}^{+}, \mathrm{K}^{+}$ -ATPase, the protonation activates to form the thiophilic drug that reacts with luminally accessed cysteines on the acid pump enzyme. It follows that the presence of acid secretion is necessary for their action. Hence it is recommended that they be given $\sim 30$ minutes before meal to ensure that the pumps are active when peak concentrations of the PPIs are present in the blood. It is also necessary to protect them from gastric acid prior to absorption. Because PPIs have a relatively short half-life and not all pumps are activated, it takes about three days to reach steady state inhibition of acid secretion as a balance is struck between covalent inhibition of active pump, subsequent stimulation of inactive pumps after the drug has been eliminated from the blood and de novo synthesis of new pumps.

The pump protein has a half life of about 54 hours in the rat (and probably in man), thus about $20 \%$ new pumps are synthesized over 24 hours. Additionally, it may be that there is greater pump synthesis at night than during the day. Bedtime administration will not add to inhibition of nocturnal acid breakthrough, since the drug will have disappeared by the time nighttime acid secretion is evident. Assuming that about $70 \%$ of pumps are activated by breakfast and that the PPI is given 30-60 minutes before, it can be calculated that steady state inhibition on

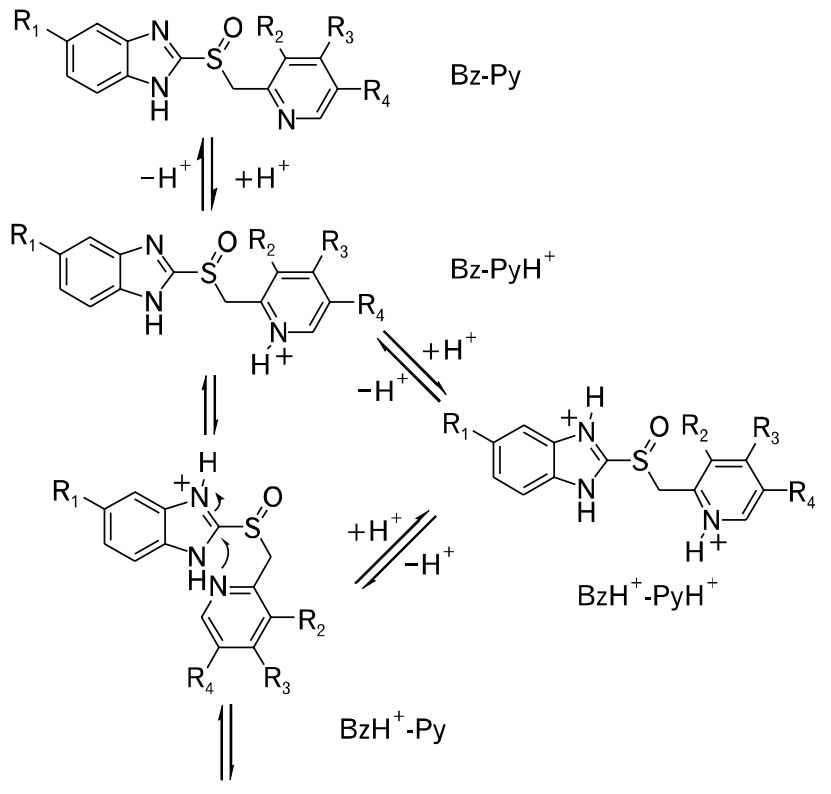

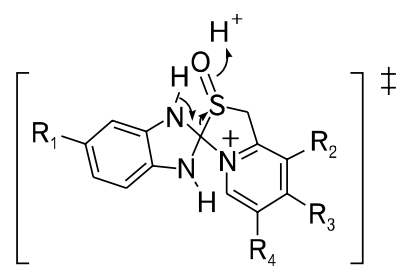

A1

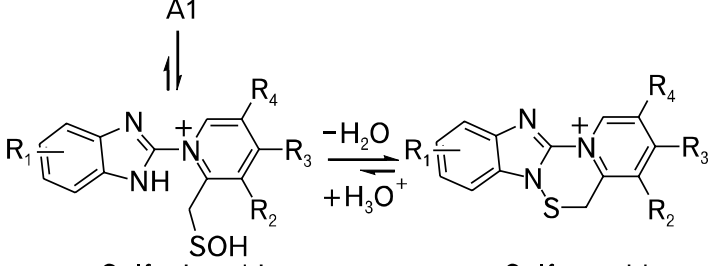

Sulfenic acid

Sulfenamide

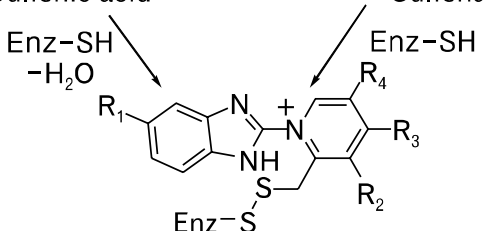

Figure 4. The mechanism of activation of the proton pump inhibitors shown in general structural form. The substituent $R_{1}, R_{2}, R_{3}$ and $R_{4}$ of the general structure $(\mathrm{Bz}-\mathrm{Py})$ represent a substituent chosen from hydrogen, methoxy, methyl and substituted alkoxy group. Top part shows the protonation of the pyridine ring and the second row of structures shows protonation also of the benzimidazole ring. The bis-protonated forms are in equilibrium with the protonated benzimidazole and unprotonated pyridine. In brackets is shown the mechanism of activation whereby the $2 \mathrm{C}$ of the protonated benzimidazole reacts with the unprotonated fraction of the pyridine moiety that results in rearrangement to a permanent cationic tetracyclic sulfenic acid which in aqueous solute dehydrates to form a cationic sulfenamide. Either of these thiophilic species can react with the enzyme to form disulfides with one or more enzyme cysteines accessible from the luminal surface of the enzyme. Adapted from Shin et al. ${ }^{27}$ 
once a day dosage is at about $66 \%$ of the maximal acid output. Increasing the dose has virtually no effect once optimal dosage has been reached, but increasing dose frequency has some effect, shown by dexlansoprazole delayed release formulation.

\section{Linear Relationship Between the Inhibition of Gastric Acid Secretion and Covalent Binding of Proton Pump Inhibitor}

The inhibition of acid secretion was compared to the binding amounts of omeprazole in vivo (Shin, unpublished data). Inhibitory activity by PPIs was linear to the binding amounts of PPIs in the pump enzyme (Fig. 5). In this experiment, radioactive omeprazole was orally administrated at a dosage of $10 \mathrm{mg} / \mathrm{kg}$ to make full inhibition, and the drug concentration in the plasma level and the inhibition of acid secretion were measured at timed intervals. Then, the stomachs were isolated at a given time and the pump enzyme was separated from each stomach. Radioactive omeprazole bound to the enzyme was counted, and the quantity of the enzyme was determined. Maximum binding of omeprazole to the pump enzyme with full inhibition of acid pumping was 2.5 $\mathrm{nmol} / \mathrm{mg}$ of the enzyme, which was fully agreed with the reported data. ${ }^{32}$ As shown in Figure 5, the inhibition of acid secretion decreased as the binding amounts of omeprazole decreased. The relationship was linear. Plasma level of the drug was not correlated

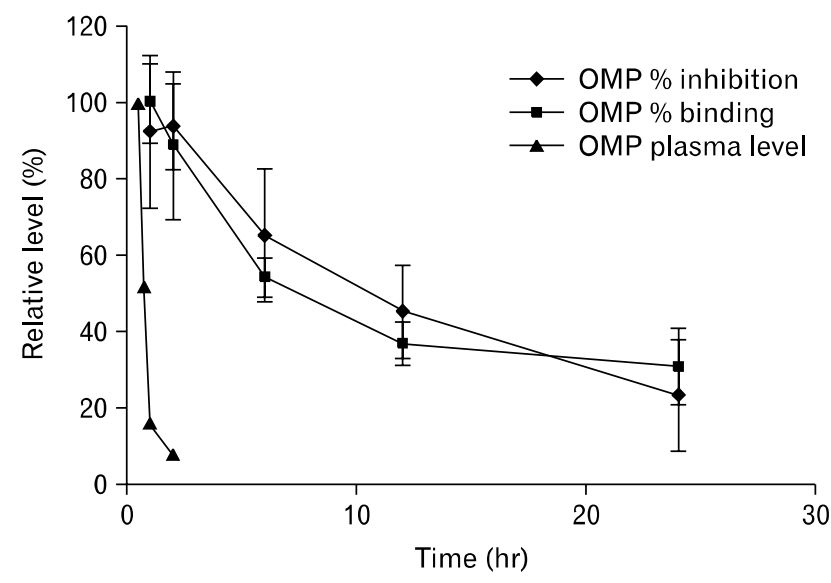

Figure 5. Comparison of $\%$ inhibition, $\%$ omeprazole (OMP) binding and $\%$ plasma level. Radioactive OMP was orally administrated at a dosage of $10 \mathrm{mg} / \mathrm{kg}$, and the drug concentration in the plasma level and the inhibition of acid secretion in the pylorus-ligated rats were measured. Then, the pump enzyme was isolated from each stomach. Radioactive OMP bound to the enzyme was measured together with quantity of the enzyme. Maximum binding stoichiometry was $2.5 \mathrm{nmol} / \mathrm{mg}$ of the enzyme. Error bar is SD $(\mathrm{n}=5)$. \% inhibition, \% inhibition of gastric acid secretion. with the inhibition or binding amounts except administration beginning time. Drug concentration in the blood abolished fast with the elimination half-life about 7-10 minutes in rats, while the inhibition prolonged since the inhibition was achieved by covalent binding of activated omeprazole. This clearly shows that measuring the plasma level of the drug cannot reveal the inhibition of the drug.

Several factors must be considered to understand the pharmacodynamics of PPIs: accumulation of PPI in the parietal cell, proportion of the pump enzyme located at the canaliculus, de novo synthesis of new pump enzyme, metabolism of PPI, amounts of covalent binding of PPI in the parietal cell and the stability of PPI binding.

\section{Stability of Proton Pump Inhibitor Binding}

If covalent binding of PPI to the enzyme is inert, only de novo biosynthesis was responsible for restoration of ATPase activity. The half-life of PPI binding will be same as the half-life of the pump enzyme. However, there was a discrepancy of half-life among the pump enzyme, the PPI binding, and the inhibition of PPI. Half-life of the rat pump enzyme was about 54 hours ${ }^{33}$ but restoration of the enzyme activity after PPI administration was about 15 hours of half-life. ${ }^{32}$ In other experiments, the half-time of restoration of acid secretion in omeprazole treated rats was 20 hours. ${ }^{34,35}$ The half-life of omeprazole in vivo bound to the enzyme in rats was about 12 hours, ${ }^{31,32}$ which was a little faster than that of the enzyme activity restoration. Activated PPI binding to the pump enzyme is achieved through the disulfide forming between the activated PPI and cysteines of the enzyme. Disulfide bond is pretty weak on reductive cleavage. In the parietal cell, there are 2-3 mM of glutathione, which can cleave the disulfide. If glutathione can access the disulfide of PPI bound enzyme, glutathione can cleave the PPI, resulting in restoration of the enzyme activity. Since omeprazole binds at Cys813 and Cys892, different accessibility of glutathione to each cysteine may result in faster cleavage. Only Cys813 bound omeprazole is responsible for the inhibition, in other words, restoration of the enzyme activity depends on the cleavage of disulfide of PPI at Cys813. Different restoration of the pump enzyme activity was observed among PPIs. Restoration of the pump activity was much slower in pantoprazole treated rats with biphasic mode. Incubation of the inhibited ATPase with glutathione resulted in a different rate of loss in the binding of omeprazole and pantoprazole. These observations showed that removal of the drug's binding to Cys 813 accounts for the fast phase of recovery of acid secretion, while the 
A

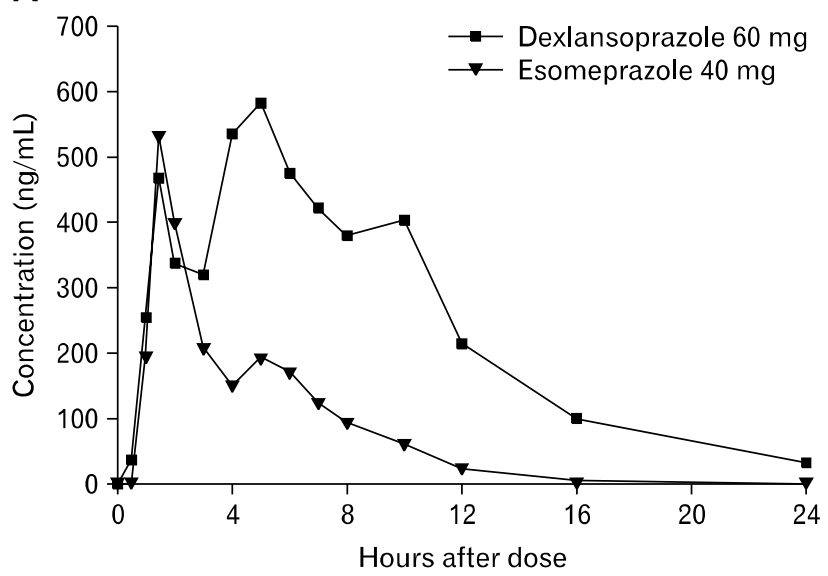

B

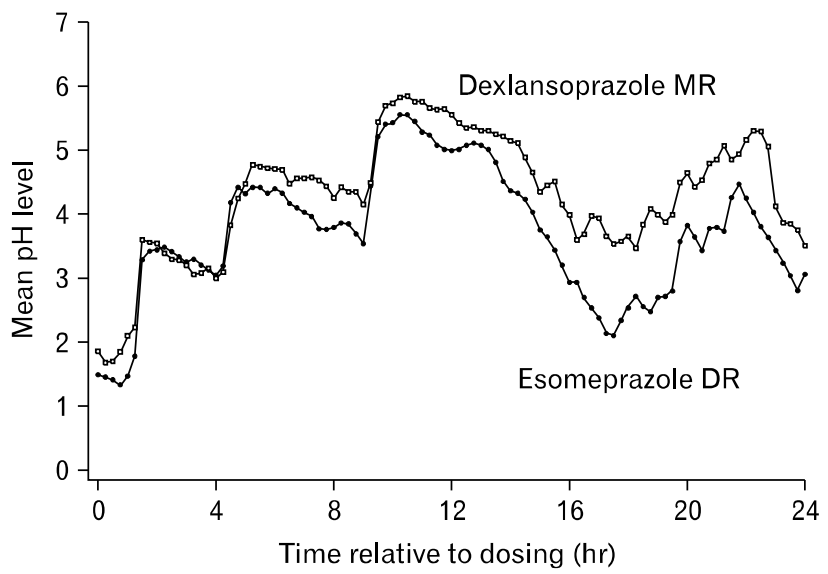

Figure 6. Comparison of dexlansoprazole modified-release (MR) and esomeprazole delayed-release (DR). (A) Mean plasma concentration-time curves of dexlansoprazole and esomeprazole after single oral doses of dexlansoprazole MR $60 \mathrm{mg}$ and esomeprazole $40 \mathrm{mg}$ DR capsule in healthy subjects. (B) Mean intragastric $\mathrm{pH}$ from 0 to 24 hours postdose after single oral doses of dexlansoprazole MR $60 \mathrm{mg}$ (open square) and esomeprazole $40 \mathrm{mg}$ DR capsule (closed circle). Adapted from Kukulka et al..$^{59}$

slow recovery occurs because of the delay in removal of the drug from Cys $822 .^{31,32}$ Both residues, Cys 813 and Cys822, are equally labeled by pantoprazole in vivo.

Thus the stability of PPI binding is one of the factors affecting the duration of the inhibitory activity.

\section{Metabolism of the Proton Pump Inhibitor}

The PPIs are inactive in their native form and are rapidly metabolized by the liver. Since PPI is an acid-activated prodrug, it is important to keep the PPI plasma level high until the gastric acid secretes. Maintaining high plasma level of the drug is significantly affected by the character of the metabolism. Metabolism of PPIs is dependent on the cytochrome P450 system. CYP2C19 and CYP3A4 polymorphism are major components for this. Omeprazole is converted to hydroxyl and 5-O-demethyl metabolites by $\mathrm{CYP} 2 \mathrm{C} 19$ and to the sulfone by CYP3A4. ${ }^{36}$ According to the metabolic rate of omeprazole, individuals are classified as homozygous extensive metabolizer (homoEM), heterozygous extensive metabolizer (heteroEM) and poor metabolizer (PM). PMs exhibit a 3 to 10 folds higher area uner the plasmic concentration curve (AUC) than homoEM, while heteroEMs exhibit a 2 to 3 folds higher AUC. ${ }^{37,38}$ The CYP2C19 genotype greatly influenced this difference. The most extensively described variant alleles for PMs are CYP2C19*2 and CYP2C19*3, which encode for nonfunctional proteins. Omeprazole is a racemic mixture of 2 enantiomers, R- omeprazole and S-omeprazole. Each enantiomer showed different affinity to the CYP enzyme.
R-omeprazole was more sensitive to CYP2C19 while S-omeprazole was less sensitive. ${ }^{39,40}$ Therefore, S-omeprazole provided better plasma level of the drug. Like omeprazole, lansoprazole also was extensively metabolized by CYP2C19 and CYP3A4. Major metabolites of lansoprazole are 5-hydroxy lansoprazole and the sulfone. Similar patterns of metabolism were observed in pantoprazole and rabeprazole.

\section{Pharmacokinetics and Pharmacodynamics of Proton Pump Inhibitor}

It is clear that the quantity of PPI bound to the enzyme is directly linked to the inhibition of gastric acid secretion. However, it is very difficult to measure the quantity of PPI binding in vivo, so we need another parameter substituting the quantity of PPI binding. As discussed above, the plasma level of the drug was not linear to the inhibitory activity. It was, however, observed that the gastric antisecretory effect was related to the total dose and AUC, whereas the peak level or the shape of the curve was of minor importance. ${ }^{41,42}$ This enables AUC to correlate with the activity. However, this relationship is only acceptable up to a certain level such as the ED50 level of dosage. Linear relationship between the inhibitory activity and AUC was not shown at higher dosage of the drug. Though the relationship between AUC and the inhibition was not linear at higher dosage of the drug due to the short half-life of the drug and the limited exposure of the enzyme to the drug, at least AUC showed the efficacy of the drug with good reliability. Unlike the animal model, the measurement of in- 
hibition of acid output in human is not easy, so measuring intragastric $\mathrm{pH}$ is used to present the inhibition due to drug activity. Actually, control of the intragastric $\mathrm{pH}$ is very important in healing acid-related diseases and eradicating Helicobacter pylori. The duration time of intragastric $\mathrm{pH}$ over 3 is crucial for healing duodenal ulcers. In order to get successful treatment of GERD, percent time of the intragastric $\mathrm{pH}>4$ should be high, ${ }^{43}$ as is true for eradicating $H$. pylori. Therefore, duration time of intragastric $\mathrm{pH}$ over 3 or 4 and mean (or median) intragastric $\mathrm{pH}$ become powerful tools in evaluating the drug's efficacy. Mean intragastric $\mathrm{pH}$ was shown to have some linearity with AUC, ${ }^{44}$ however, the degree of acid suppression shown by intragastric $\mathrm{pH}$ profile would be the best in vivo parameter with which to compare the potency of PPIs.

All PPIs have about 1 hour of the elimination half-life, but the time to maximum plasma concentration $\left(t_{\max }\right)$ was widely deviated from 1 hour to 5 hours by drug formulation and/or food effect. Pharmacokinetic properties are summarized in Table.

After the clinical efficacy of omeprazole $20 \mathrm{mg}$ was well studied, other PPIs were compared to omeprazole. For example, lansoprazole $30 \mathrm{mg}$ was compared to omeprazole $20 \mathrm{mg}$. One study showed slightly improved acid suppression by lansoprazole 30 $\mathrm{mg}^{45}$ while another study showed no significant difference. ${ }^{46}$ Lansoprazole $30 \mathrm{mg}$ was not superior to omeprazole $40 \mathrm{mg} .{ }^{47}$ When pantoprazole $40 \mathrm{mg}$ was compared with omeprazole 20 $\mathrm{mg}$, a significantly higher daytime $\mathrm{pH}$ on both day 1 and 7 was observed with pantoprazole, ${ }^{48}$ however pantoprazole and omeprazole have a similar potency on a $\mathrm{mg}$ for $\mathrm{mg}$ basis. Generally speaking, omeprazole, lansoprazole, pantoprazole and rabeprazole have similar efficacy for healing the acid-related diseases.

S-omeprazole has an advantage on metabolism as its plasma concentration is higher than that of omeprazole. AUC of S-omeprazole was much higher than that of omeprazole. Thus, S-omeprazole, named as esomeprazole, gave improved intragastric $\mathrm{pH}$ profile as expected. For instance, Lind et $\mathrm{al}^{49}$ reported that mean duration time with intragastric $\mathrm{pH}>4$ was 16.8 hours and 24-hour median intragastric $\mathrm{pH} 4.9$ was measured by esomeprazole $40 \mathrm{mg}$.

All studies related with esomeprazole demonstrated that esomeprazole $40 \mathrm{mg}$ once daily (od) is superior to all other PPIs at standard doses in terms of achieving higher 24-hour median intragastric $\mathrm{pH}$ and the number of patients achieving intragastric $\mathrm{pH} \geq 4.0$ for at least 12 hours per day. Since esomeprazole was superior to other PPIs for acid suppression, better healing rates on acid-related diseases were achieved. Clinical studies demonstrated that esomeprazole $40 \mathrm{mg}$ od for up to 8 weeks provided higher rates of healing of erosive GERD, along with a greater proportion of patients with sustained resolution of heartburn, than omeprazole $20 \mathrm{mg}$, lansoprazole $30 \mathrm{mg}$, or pantoprazole 40 mg od. ${ }^{50-52}$

The metabolic advantage of esomeprazole increases the plasma concentration, resulting in higher AUC, however its short half-life (60-90 minutes) is still the key issue in drug efficacy. There is no drug present at night. In order to keep reasonable plasma level of the drug, twice-daily dosing was designed and provided significantly greater acid suppression than once-daily dosing. Esomeprazole $40 \mathrm{mg}$ bd has also been shown to be superior to pantoprazole $40 \mathrm{mg}$ bd and lansoprazole $30 \mathrm{mg}$ bd in maintaining intragastric $\mathrm{pH}$ at 4.0 or lower. Twice-daily dosing of esomeprazole provides significantly greater acid suppression than once-daily dosing and may, therefore, be a reasonable consideration for patients requiring greater acid-suppression for GERD. ${ }^{53-56}$

Recently a novel formulation of the R-enantiomer of lansoprazole has been introduced. This is a dual release formulation of $60 \mathrm{mg}$ of PPI with normal enteric coating release at around $\mathrm{pH}$ 5.0 and a coating labile at $\mathrm{pH} 7.0$ releasing dexlansoprazole some hours later to try to provide night time drug levels. ${ }^{57}$ A similar

Table. Pharmacokinetic Property of Proton Pump Inhibitors ${ }^{49,62-64}$

\begin{tabular}{|c|c|c|c|c|c|}
\hline Parameter & Omeprazole $20 \mathrm{mg}$ & Lansoprazole $30 \mathrm{mg}$ & Pantoprazole $40 \mathrm{mg}$ & Rabeprazole $20 \mathrm{mg}$ & Esomeprazole \\
\hline $\mathrm{t}_{\max }(\mathrm{hr})$ & $1-4$ & $1.2-2.1$ & $2-4$ & $3-5$ & $1.0-3.5$ \\
\hline $\mathrm{C}_{\max }(\mu \mathrm{mol} / \mathrm{L})$ & $0.23-23.2$ & $1.62-3.25$ & $2.87-8.61$ & 1.14 & $2.1-2.4$ at $20 \mathrm{mg}, 4.7-5.1$ at $40 \mathrm{mg}$ \\
\hline $\mathrm{AUC}(\mu \mathrm{mol} \cdot \mathrm{hr} / \mathrm{L})$ & $0.58-3.47$ & $4.6-13.5$ & $5.22-13.04$ & 2.22 & 4.2 at $20 \mathrm{mg}, 12.6$ at $40 \mathrm{mg}$ \\
\hline V (L/kg) & $0.13-0.35$ & 0.4 & 0.15 & & $0.22-0.26$ \\
\hline $\mathrm{CL}(\mathrm{mL} / \mathrm{min})$ & $400-620$ & $400-650$ & $90-225$ & & $160-330$ \\
\hline $\mathrm{t}_{1 / 2}(\mathrm{hr})$ & $0.5-1.2$ & $0.9-2.1$ & $0.8-2.0$ & $0.6-1.4$ & $1.3-1.6$ \\
\hline
\end{tabular}

$\mathrm{t}_{\max }$, time to maximal plasma concentration; $\mathrm{C}_{\max }$, maximal plasma concentration; AUC, area under the plasmic concentration curve; $\mathrm{V}$, apparent volume of distribution; $\mathrm{CL}$, clearance; $\mathrm{t}_{1 / 2}$, elimination half-life. 
strategy has been adopted for rabeprazole. ${ }^{58}$

Dexlansoprazole delayed-release (DR) $60 \mathrm{mg}$ gave better control of intragastric $\mathrm{pH}$ than esomeprazole $40 \mathrm{mg}$ (Fig. 6). Mean gastric $\mathrm{pH}$ values for dexlansoprazole $\mathrm{DR}$ and esomeprazole were 4.3 and 3.7 respectively. Night time $\mathrm{pH}$ control was significantly improved with dexlansoprazole. At $>12-24$ hours postdose, mean percentage of time with $\mathrm{pH}>4$ and average of mean $\mathrm{pH}$ were $60 \%$ and 4.5 respectively. Under the same situation, esomeprazole showed $42 \%$ of mean percentage of time with $\mathrm{pH}>4$ and an average of mean $\mathrm{pH} 3.5$. $^{59}$

Rabeprazole extended-release (ER) $50 \mathrm{mg}$ formulation was developed to provide prolonged gastric acid suppression and potentially improved clinical outcomes in GERD patients. One study shows that Rabeprazole ER groups provided mean durations of $18.5-20.2$ hours (77.0-84.1\% of 24-hour) with intragastric $\mathrm{pH}>4.0$ vs. esomeprazole $40 \mathrm{mg}$ ( 15.9 hours $/ 66.1 \%$ of 24-hour) on day 5. Percentage of night-time (10 pm-8 am) with intragastric $\mathrm{pH}>4.0$ was higher with the rabeprazole ER groups (57.0-72.4\%) vs. esomeprazole $40 \mathrm{mg}$ (32.8\%). ${ }^{60}$

Modified-release or ER of PPIs apparently has longer effective plasma concentration. This provides a better chance to block the gastric $\mathrm{H}^{+}, \mathrm{K}^{+}$-ATPase activity, which allows better intragastric $\mathrm{pH}$ control.

There have been some concerns about the safety of PPIs. The Food and Drug Administration (FDA) has warned against the use of certain PPIs by patients on clopidogrel. However, a randomized controlled trial that compared clopidogrel alone with the combination of clopidogrel and omeprazole found no increase in adverse cardiovascular outcomes and a reduction in the rate of adverse gastrointestinal outcomes attributable to omeprazole. ${ }^{61}$

\section{Conclusion}

Since PPIs were introduced, considerable progress has been achieved in the management of acid-related diseases. The intragastric target $\mathrm{pH}$ can be maintained above the threshold level of $>3$ (peptic ulcer) or $>4$ (GERD) by PPIs. Metabolism of PPI was different among individuals. There are three groups of metabolizers: homoEM, heteroEM and PM, as described above. This difference was from the variation of CYP2C19 phenotype. Specific enantiomers such as S-omeprazole and R-lansoprazole had significant advantage over the CYP2C19 enzyme. Better control of the intragastric $\mathrm{pH}$ was achieved by this specific enantiomer.

Though the shape of the plasma concentration curve or the peak level was of minor importance, AUC was relatively linear-fit with the antisecretory inhibition. Good linearity was observed between the amounts of PPI binding and the inhibition. Measuring the intragastric $\mathrm{pH}$ and AUC is enough to judge the drug efficacy. DR or ER of the drug enabled the night time $\mathrm{pH}$ control due to prolonged time of effective plasma concentration.

In patients with GERD, standard doses of esomeprazole and dexlansoprazole maintain intragastric $\mathrm{pH}$ above 4 for significantly longer periods compared with standard doses of other PPIs after 5 days of treatment. PPI treatment in GERD has been reported to result in the improvement of health-related quality of life indices.

\section{Acknowledgements}

Authors appreciate Dr. George Sachs and Dr. Keith Munson for informative suggestions for the function and the structure of the pump enzyme.

\section{References}

1. Black JW, Duncan WA, Durant CJ, Ganellin CR, Parsons ME. Definition and antagonism of histamine H2-receptors. Nature 1972;236:385-390.

2. Fellenius E, Berglindh T, Sachs G, et al. Substituted benzimidazoles inhibit gastric acid secretion by blocking $\left(\mathrm{H}^{+}+\mathrm{K}^{+}\right)$ATPase. Nature 1981;290:159-161.

3. Okabe S, Takeuchi K, Urushidani T, Takagi K. Effects of cimetidine, a histamine $\mathrm{H}_{2}$-receptor antagonist, on various experimental gastric and duodenal ulcers. Am J Dig Dis 1977;22:677-684.

4. Walderhaug MO, Post RL, Saccomani G, Leonard RT, Briskin DP. Structural relatedness of three ion-transport adenosine triphosphatases around their active sites of phosphorylation. J Biol Chem 1985;260:3852-3859.

5. Bamberg K, Sachs G. Topological analysis of $\mathrm{H}^{+}, \mathrm{K}^{+}$-ATPase using in vitro translation. J Biol Chem 1994;269:16909-16919.

6. Besancon M, Shin JM, Mercier F, et al. Membrane topology and omeprazole labeling of the gastric $\mathrm{H}^{+}, \mathrm{K}^{+}$- adenosinetriphosphatase. Biochemistry 1993;32:2345-2355.

7. Shin JM, Besancon M, Simon A, et al. The site of action of pantoprazole in the gastric $\mathrm{H}^{+}, \mathrm{K}^{+}$- ATPase. Biochim Biophys Acta 1993;1148:223-233.

8. Kirley TL. Determination of three disulfide bonds and one free sulfhydryl in the beta subunit of $\left(\mathrm{Na}^{+}, \mathrm{K}^{+}\right)$-ATPase. J Biol Chem 1989;264:7185-7192.

9. Chow DC, Browning CM, Forte JG. Gastric $\mathrm{H}^{+}, \mathrm{K}^{+}$- ATPase activity is inhibited by reduction of disulfide bonds in beta-subunit. Am J Physiol 1992;263(1 Pt 1):C39-C46.

10. Callaghan JM, Toh BH, Pettitt JM, Humphris DC, Gleeson PA. Poly-N-acetyllactosamine-specific tomato lectin interacts with gastric parietal cells. Identification of a tomato-lectin binding 60-90 X 10(3) 
Mr membrane glycoprotein of tubulovesicles. J Cell Sci 1990;95(Pt 4):563-576.

11. Reuben MA, Lasater LS, Sachs G. Characterization of a beta subunit of the gastric $\mathrm{H}^{+}, \mathrm{K}^{+}$- transporting ATPase. Proc Natl Acad Sci USA 1990;87:6767-6771.

12. Toh BH, Gleeson PA, Simpson RJ, et al. The 60- to 90-kDa parietal cell autoantigen associated with autoimmune gastritis is a beta subunit of the gastric $\mathrm{H}^{+}, \mathrm{K}^{+}$- ATPase (proton pump). Proc Natl Acad Sci USA 1990;87:6418-6422.

13. Shin JM, Sachs G. Identification of a region of the $\mathrm{H}^{+}, \mathrm{K}^{+}$-ATPase alpha subunit associated with the beta subunit. J Biol Chem 1994; 269:8642-8646.

14. Shin JM, Grundler G, Senn-Bilfinger J, Simon WA, Sachs G. Functional Consequences of the Oligomeric Form of the Membrane-Bound Gastric $\mathrm{H}^{+}, \mathrm{K}^{+}$-ATPase. Biochemistry 2005;44: 16321-16332.

15. Abe K, Tani K, Nishizawa T, Fujiyoshi Y. Inter-subunit interaction of gastric $\mathrm{H}^{+}, \mathrm{K}^{+}$- ATPase prevents reverse reaction of the transport cycle. EMBO J 2009;28:1637-1643.

16. Abe K, Tani K, Fujiyoshi Y. Conformational rearrangement of gastric $\mathrm{H}^{+}, \mathrm{K}^{+}$- ATPase induced by an acid suppressant. Nat Commun 2011;2:155.

17. Brzezinski P, Malmströ BG, Lorentzon P, Wallmark B. The catalytic mechanism of gastric $\mathrm{H}^{+}, \mathrm{K}^{+}$-ATPase: simulations of presteady-state and steady-state kinetic results. Biochim Biophys Acta 1988;942:215-219.

18. Shin JM, Goldshleger R, Munson KB, Sachs G, Karlish SJ. Selective $\mathrm{Fe}^{2+}$-catalyzed oxidative cleavage of gastric $\mathrm{H}^{+}, \mathrm{K}^{+}$ATPase: implications for the energy transduction mechanism of P-type cation pumps. J Biol Chem 2001;276:48440-48450.

19. Post RL, Toda G, Rogers FN. Phosphorylation by inorganic phosphate of sodium plus potassium ion transport adenosine triphosphatase. Four reactive states. J Biol Chem 1975;250:691-701.

20. Shin JM, Munson K, Sachs G. Gastric $\mathrm{H}^{+}, \mathrm{K}^{+}$-ATPase. Compr Physiol 2011;1:2141-2153.

21. Wallmark B, Brändström A, Larsson $H$. Evidence for acid-induced transformation of omeprazole into an active inhibitor of $\mathrm{H}^{+}, \mathrm{K}^{+}$ATPase within the parietal cell. Biochim Biophys Acta 1984;778: 549-558.

22. Fujisaki $H$, Shibata $H$, Oketani $K$, et al. Effects of the proton pump inhibitor, E3810, on gastric secretion and gastric and duodenal ulcers or erosion in rats. Drug Invest 1991;3:328-332.

23. Nagaya H, Satoh H, Kubo K, Maki Y. Possible mechanism for the inhibition of gastric $\left(\mathrm{H}^{+}+\mathrm{K}^{+}\right)$-adenosine triphosphatase by the proton pump inhibitor AG-1749. J Pharmacol Exp Ther 1989;248: 799-805.

24. Simon WA, Büdingen C, Fahr S, Kinder B, Koske M. The $\mathrm{H}^{+}, \mathrm{K}^{+}$ - ATPase inhibitor pantoprazole (BY1023/SK\&F96022) interacts less with cytochrome P450 than omeprazole and lansoprazole. Biochem Pharmacol 1991;42:347-355.

25. Besancon M, Simon A, Sachs G, Shin JM. Sites of reaction of the gastric H, K-ATPase with extracytoplasmic thiol reagents. J Biol Chem 1997;272:22438-22446.

26. Shin JM, Besancon M, Prinz C, Simon A, Sachs G. Continuing development of acid pump inhibitors: site of action of pantoprazole. Aliment Pharmacol Ther 1994;8(suppl 1):11-23.
27. Shin JM, Cho YM, Sachs G. Chemistry of covalent inhibition of the gastric $\left(\mathrm{H}^{+}, \mathrm{K}^{+}\right)$-ATPase by proton pump inhibitors. J Am Chem Soc 2004;126:7800-7811.

28. Keeling DJ, Fallowfield C, Underwood AH. The specificity of omeprazole as an $\left(\mathrm{H}^{+}+\mathrm{K}^{+}\right)$-ATPase inhibitor depends upon the means of its activation. Biochem Pharmacol 1987;36:339-344.

29. Lorentzon P, Jackson R, Wallmark B, Sachs G. Inhibition of $\left(\mathrm{H}^{+}\right.$ $+\mathrm{K}^{+}$)-ATPase by omeprazole in isolated gastric vesicles requires proton transport. Biochim Biophys Acta 1987;897:41-51.

30. Asano S, Yoshida A, Yashiro H, et al. The cavity structure for docking the $\mathrm{K}^{+}$-competitive inhibitors in the gastric proton pump. J Biol Chem 2004;279:13968-13975.

31. Shin JM, Sachs G. Differences in binding properties of two proton pump inhibitors on the gastric $\mathrm{H}^{+}, \mathrm{K}^{+}$-ATPase in vivo. Biochem Pharmacol 2004;68:2117-2127.

32. Shin JM, Sachs G. Restoration of acid secretion following treatment with proton pump inhibitors. Gastroenterology 2002;123:1588-1597.

33. Gedda K, Scott D, Besancon M, Lorentzon P, Sachs G. Turnover of the gastric $\mathrm{H}^{+}, \mathrm{K}^{+}$-adenosine triphosphatase alpha subunit and its effect on inhibition of rat gastric acid secretion. Gastroenterology 1995; 109:1134-1141.

34. Im WB, Blakeman DP, Davis JP. Irreversible inactivation of rat gastric $\left(\mathrm{H}^{+}-\mathrm{K}^{+}\right)$-ATPase in vivo by omeprazole. Biochem Biophys Res Commun 1985;126:78-82.

35. Wallmark B, Larsson H, Humble L. The relationship between gastric acid secretion and gastric $\mathrm{H}^{+}, \mathrm{K}^{+}$- ATPase activity. J Biol Chem 1985;260:13681-13684.

36. Furuta T, Shirai N, Sugimoto M, Nakamura A, Hishida A, Ishizaki T. Influence of CYP2C19 pharmacogenetic polymorphism on proton pump inhibitor-based therapies. Drug Metab Pharmacokinet 2005;20:153-167.

37. Klotz U, Schwab M, Treiber G. CYP2C19 polymorphism and proton pump inhibitors. Basic Clin Pharmacol Toxicol 2004;95:2-8.

38. Klotz U. Clinical impact of CYP2C19 polymorphism on the action of proton pump inhibitors: a review of a special problem. Int J Clin Pharmacol Ther 2006;44:297-302.

39. Abelö A, Andersson TB, Antonsson M, Naudot AK, Skånberg I, Weidolf L. Stereoselective metabolism of omeprazole by human cytochrome P450 enzymes. Drug Metab Dispos 2000;28:966-972.

40. Andersson T, Hassan-Alin M, Hasselgren G, Röhss K, Weidolf L. Pharmacokinetic studies with esomeprazole, the (S)-isomer of omeprazole. Clin Pharmacokinet 2001;40:411-426.

41. Larsson H, Carlsson E, Junggren U, et al. Inhibition of gastric acid secretion by omeprazole in the dog and rat. Gastroenterology 1983; 85:900-907.

42. Larsson H, Mattson H, Sundell G,Carlsson E. Animal pharmacodynamics of omeprazole. A survey of its pharmacological properties in vivo. Scand J Gastroenterol 1985;20(suppl 108):23-35.

43. Bell NJ, Burget D, Howden CW,Wilkinson J, Hunt RH. Appropriate acid suppression for the management of gastro-oesophageal reflux disease. Digestion 1992;51(suppl 1):59-67.

44. Furuta T, Ohashi K, Kosuge K, et al. CYP2C19 genotype status and effect of omeprazole on intragastric $\mathrm{pH}$ in humans. Clin Pharmacol Ther 1999;65:552-561.

45. Bruley des Varannes S, Levy P, Lartigue S, Dellatolas F, Lemaire $\mathrm{M}$, Galmiche JP. Comparison of lansoprazole with omeprazole on 
24-hour intragastric $\mathrm{pH}$, acid secretion and serum gastrin in healthy volunteers. Aliment Pharmacol Ther 1994;8:309-314.

46. Geus WP, Mulder PG, Nicolai JJ, Van den Boomgaard DM, Lamers CB. Acid-inhibitory effects of omeprazole and lansoprazole in Helicobacter pylori-negative healthy subjects. Aliment Pharmacol Ther 1998;12:329-335.

47. Timmer W, Ripke H, Kleist P, et al. Effect of four lansoprazole dose levels and one dosage regimen of omeprazole on 24-hour intragastric pH in healthy subjects. Methods Find Exp Clin Pharmacol 1995;17: 489-495.

48. Hartmann M, Theiss U, Huber R, et al. Twenty-four-hour intragastric $\mathrm{pH}$ profiles and pharmacokinetics following single and repeated oral administration of the proton pump inhibitor pantoprazole in comparison to omeprazole. Aliment Pharmacol Ther 1996;10:359-366.

49. Lind T, Rydberg L, Kylebäck A, et al. Esomeprazole provides improved acid control vs. omeprazole In patients with symptoms of gastro-oesophageal reflux disease. Aliment Pharmacol Ther 2000;14: 861-867.

50. Miner P Jr, Katz PO, Chen Y, Sostek M. Gastric acid control with esomeprazole, lansoprazole, omeprazole, pantoprazole, and rabeprazole: a five-way crossover study. Am J Gastroenterol 2003;98:26162620.

51. Wilder-Smith CH, Röhss K, Nilsson-Pieschl C, Junghard O, Nyman L. Esomeprazole $40 \mathrm{mg}$ provides improved intragastric acid control as compared with lansoprazole $30 \mathrm{mg}$ and rabeprazole $20 \mathrm{mg}$ in healthy volunteers. Digestion 2003;68:184-188.

52. Rohss K, Lind T, Wilder-Smith C. Esomeprazole $40 \mathrm{mg}$ provides more effective intragastric acid control than lansoprazole $30 \mathrm{mg}$, omeprazole $20 \mathrm{mg}$, pantoprazole $40 \mathrm{mg}$ and rabeprazole $20 \mathrm{mg}$ in patients with gastro-oesophageal reflux symptoms. Eur J Clin Pharmacol 2004;60:531-539.

53. Katz PO, Castell DO, Chen Y, Andersson T, Sostek MB. Intragastric acid suppression and pharmacokinetics of twice-daily esomeprazole: a randomized, three-way crossover study. Aliment Pharmacol Ther 2004;20:399-406.

54. Morgner-Miehlke A, Petersen K, Miehlke S, Labenz J. Esomeprazole: potent acid suppression in the treatment of acid-related disorders. Expert Rev Clin Immunol 2005;1:511-527.
55. Johnson DA, Stacy T, Ryan M, et al. A comparison of esomeprazole and lansoprazole for control of intragastric $\mathrm{pH}$ in patients with symptoms of gastro-oesophageal reflux disease. Aliment Pharmacol Ther 2005;22:129-134.

56. Kalaitzakis E, Björnsson E. A review of esomeprazole in the treatment of gastroesophageal reflux disease (GERD). Ther Clin Risk Manag 2007;3:653-663.

57. Katz PO, Koch FK, Ballard ED, et al. Comparison of the effects of immediate-release omeprazole oral suspension, delayed-release lansoprazole capsules and delayed-release esomeprazole capsules on nocturnal gastric acidity after bedtime dosing in patients with night-time GERD symptoms. Aliment Pharmacol Ther 2007;25:197-205.

58. Laine L, Katz PO, Johnson DA, et al. Randomised clinical trial: a novel rabeprazole extended release $50 \mathrm{mg}$ formulation vs. esomeprazole $40 \mathrm{mg}$ in healing of moderate-to-severe erosive oesophagitis - the results of two double-blind studies. Aliment Pharmacol Ther 2011; 33:203-212.

59. Kukulka M, Eisenberg C, Nudurupati S. Comparator pH study to evaluate the single-dose pharmacodynamics of dual delayed-release dexlansoprazole $60 \mathrm{mg}$ and delayed-release esomeprazole $40 \mathrm{mg}$. Clin Exp Gastroenterol 2011;4:213-220.

60. Morelli G, Chen H, Rossiter G, Rege B, Lu Y. An open-label, parallel, multiple-dose study comparing the pharmacokinetics and gastric acid suppression of rabeprazole extended-release with esomeprazole $40 \mathrm{mg}$ and rabeprazole delayed-release $20 \mathrm{mg}$ in healthy volunteers. Aliment Pharmacol Ther 2011;33:845-854.

61. Chen J, Yuan YC, Leontiadis GI, Howden CW. Recent safety concerns with proton pump inhibitors. J Clin Gastroenterol 2012;46:93114 .

62. Shi S, Klotz U. Proton pump inhibitors: an update of their clinical use and pharmacokinetics. Eur J Clin Pharmacol 2008;64:935-951.

63. Junghard O, Hassan-Alin M, Hasselgren G. The effect of the area under the plasma concentration vs time curve and the maximum plasma concentration of esomeprazole on intragastric $\mathrm{pH}$. Eur J Clin Pharmacol 2002;58:453-458.

64. Stedman CA, Barclay ML. Review article: comparison of the pharmacokinetics, acid suppression and efficacy of proton pump inhibitors. Aliment Pharmacol Ther 2000;14:963-978. 